\title{
物理的処理による淡水赤潮対策の効果に関する 基礎的実験
}

\author{
THE EFFECTS OF PHYSICAL TREATMENT ON FRESHWATER RED TIDE \\ FORMING DINOFLAGELLLATE (PERIDINIUM): EXPERIMENTAL STUDY
}

\author{
古里 栄一 ${ }^{1}$. 久納 誠 $^{2} \cdot$ 有田正光 ${ }^{3}$ \\ Eiichi FURUSATO, Makoto KUNOU and Masamitsu ARITA \\ 1正会員 博(工) 東京電機大学研究員 理工学部建設環境工学科（テ350-0394 埼玉県比企郡鳩山町石坂） \\ 2正会員 博(工) 独立行政法人水資源機構審議役 総合技術センター（テ330-6008 埼玉県さいたま市中央 \\ 区新都心11番地2） \\ 3正会員 工博 東京電機大学教授 理工学部建設環境工学科（于350-0394 埼玉県比企郡鳩山町石坂）
}

\begin{abstract}
We carried out experimental study investigating the effects of physical treatment on dinoflagellate (Peridinium bipes) in order to develop measure to prevent freshwater red tide in reservoirs. Surface water in the reservoir occurring freshwater red tide was sampled for the physical treatments. We found that physical treatment caused cessation of swimming of $P$. bipes and subsequently effects on water quality and plankton composition. Immediately after physical treatment, almost of all cells of $P$. bipes stopped swimming behavior. However, one day after treatment, about $70 \%$ of cells restarted swimming. This ratio maintained 12 day after the treatment. Settlement of stopping cells led decrease in concentration of Chla and SS. Considering these effects, we discussed mechanism of effects of physical treatment on Peridinium dynamics and counter measure preventing freshwater red tide.
\end{abstract}

Key Words : freshwater red tides, dinoflagellate, Peridinium, swimming, physical treatment

\section{1. はじめに}

筆者らは前報において，アオコを形成する藍藻類の増 殖を抑制する物理的手法について報告した ${ }^{1)}$. アオコ形 成藍藻類の競合戦略の無効化作用として高圧によるガス 胞破壊と強い乱れによる群体構造の破壊を生じさせ，沈 降と捕食により個体群の減少によるアオコ発生抑制や水 質浄化を図る物理的手法を提案した.

淡水赤潮は浻鞭毛藻類によって生じるものであり，ダ 么貯水池の景観障害を引き起こし貯水池の親水機能を劣 化させる ${ }^{2}$. 淡水赤潮を形成する渦鞭毛藻類(以降では赤 潮藻類と記述)の生活史 ${ }^{3}$ やシストの発芽条件 ${ }^{4)}$, 栄養細 胞の水温や光等の環境条件に対する要求性)や遊泳特性 3),などについて，これまでに多くの研究が行われている. また, 現地の貯水池の密度流場における生態学的な赤潮 発生機構についても，現地調查(3),7,8)や数值モデル9)12) に よる検討が行われてきている，このように，淡水赤潮の 発生メカニズムについては多くの知見が蓄積されつつあ るのに対して，対策手法については幾つかの研究開発例

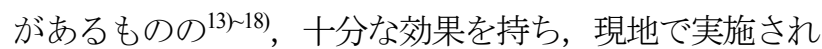
ている技術として確立されているものはない22,19). 本研 究は, 前報で使用したアオコ対策実験と類似の装置を使 用して赤潮藻類(Peridinium) への効果を実験的に検討し， 淡水赤潮対策手法を提案寸るものである.

なお，既に井芹ら ${ }^{20}$ は，本報と同様の装置を鞭毛藻類 のCeratium hirundinellaに対して使用し，増殖抑制効果が あることを報告しているが詳細な効果メカニズムは不明 であった. 一方本研究で対象とするPeridiniumについて は，定性的には遊泳能力の消失が確認されているものの 21)，これまでに実験データの報告例は無い.

\section{2. 淡水赤潮抑制対策の現地実験}

\section{（1）現地実験方法}

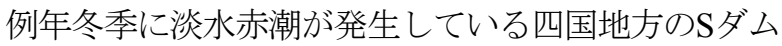
貯水池を現地実験の対象とし, 淡水赤潮が発生していた 平成17年1月10日に貯水池上流水域で表層水を試料水と して採水した. 採水した表層水中の植物プランクトンの 
99\%以上は渦鞭毛藻類のPeridinium bipes f. occultatum で あった. 採水時にはP. bipesは水深 $1 \mathrm{~m}$ 付近まで比較的均 質に分布し,極端な水面集積は観察されなかった．採水 箇所の表層水の水質は機器観測によると, Chl-a濃度 : $26.7 \mu \mathrm{g} / \mathrm{L}$, 濁度 : 7.2度, DO : $11.5 \mathrm{mg} / \mathrm{L}, \mathrm{pH}: 8.3$, 水温 : $7.2^{\circ} \mathrm{C}$ であった。

採水から処理実験までの諸作業はPeridiniumへのダ メージを小さくすることに留意して行った．試料水の採 水は表層数 $10 \mathrm{~cm}$ の湖沼水を作業船上からバケツで穏や かに取水してポリタンクに注ぎ，微速航行で陸上の実験 ヤードまで約1時間かけて輸送した. なお，ポンプなど の機械は使用せず人力で注意深く実施した．実験ヤード では採取した試料水を約 $1 \mathrm{~m}^{3}$ のタンクに穏やかに移して 約1時間静置した上で，採水や輸送作業で生じたストレ スで遊泳停止した赤潮藻類を沈降させた後, 遊泳細胞の み存在すると考えられる上澄み水をサイフォンで実験装 置に静かに移した.

使用した実験装置はアオコ対策に使用した前報 ${ }^{1)}$ と同 様な装置であり，概略を図-1に示す，装置の構成は処理 水の移動経路に沿って，処理前タンク，水中ポンプ，送 水管, 射出ノズル，衝撃盤とからなる(図中の矢印は処 理水の片方向の移動経路を示す). 水中ポンプは，株式 会社シントー社製(口径・型式: 32(25) - SUM, 型番: 32S4K-2.218-6(A)) であり，吐出量は0.035〜0.1110 $\left[\mathrm{m}^{3} / \mathrm{min}\right]$, 全揚程は136〜66[m], 段数は18であり, Franklin Electric社製のモーター(型式: 2343862504, 出 力:2.2[kW])を駆動装置として使用している。実験にあ たっては, 射出ノズルの径を調整して, 射出部の径を $5[\mathrm{~mm}]$ とした. これは，ポンプ出口圧力としてゲージ圧 で0.67Mpaに相当し，流量は約 $0.07\left[\mathrm{~m}^{3} / \mathrm{min}\right]$ となる．送水 管の長さは水平部で $80 \mathrm{~cm}$ であり, 内径は，圧力計まで の基部側が40[mm]，下流側が20[mm]である.

実験装置で処理した試料水は，一旦約60Lの容器に入 れた後に十分に覺拌して均一化した後，遊泳細胞計測用 として $50 \mathrm{~mL}$ の小容器にその一部を移して上澄み水の時 系列変化を把握するためのサンプルとして自然光の当た る室内の空側の容器に静置した.

処理によるPeridiniumの遊泳状態について論ずるため に, 細胞数は遊泳細胞, 遊泳停止細胞, 枯死細胞（壳の みの細胞）に分類して顕微鏡計測した(表 1). 処理直後 に分注した小容器を十分に攪拌した後に計測用プレパ ラートに $1 \mathrm{~mL}$ 移して採取後数 10 分以内に現地で顕微鏡で 細胞数を計測した. この計測は1条件あたり3プレパラー 卜を作成して実施した．細胞数の計測は，処理直後，処 理3時間後, 処理1日後, 処理2日後, 処理12日後の5回と した。また，処理後のPeridinium細胞沈降による上澄み 水質への影響を評価するために，60L容器の上澄み水の Chl-a, SS, T-Pの濃度と, 植物プランクトン, 動物プラ ンクトンの細胞数を, 処理前, 処理直後, 処理12日後に 分析した. 分析方法は常法 ${ }^{22)}$ にった. 植物・動物プラ

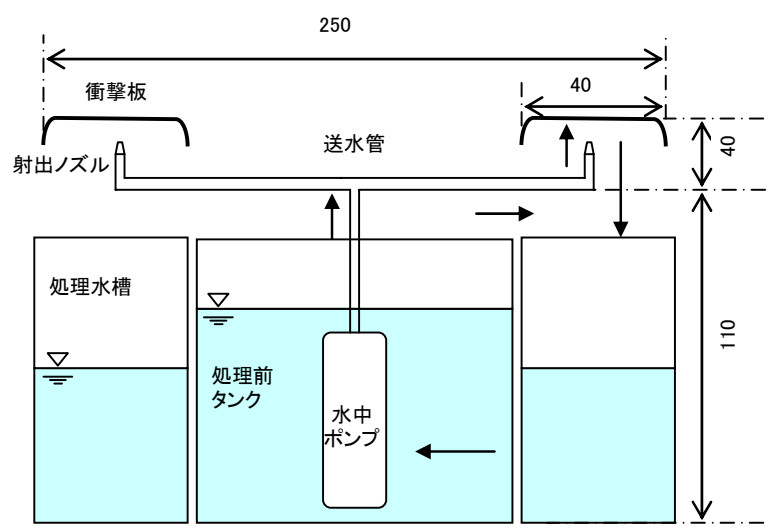

図-1＼cjkstart実験装置の概要(サイズの単位はcm)

表-1 Peridiniun細胞の遊泳状態の分類

\begin{tabular}{|l|l|}
\hline 細胞の分類 & 定義 \\
\hline 遊泳細胞 & 回転および前進等の遊泳運動が観察された細胞 \\
\hline 停止細胞 & 遊泳が確認できない細胞 \\
\hline 枯死細胞 & 処理12日後に観測された, 殼のみの細胞 \\
\hline
\end{tabular}

ンクトンはホルマリン固定して光学顕微鏡により種別の 細胞数を計測した。これらの各分析は，処理の効果を検 討するために，無処理サンプル(ケースA)も処理サンプ ル(ケースB)と同時に分析を行った.

\section{（2）実験結果}

以下では実験装置による物理的処理の効果として, Peridiniumの遊泳状態への影響に加えて，上澄み水質お よびプランクトンへの影響について論ずる.

\section{a）処理による細胞の遊泳状態への影響}

図-2に処理の有無におけるPeridinium細胞の遊泳状態 の経時変化を示した。 なお，各困の左端の無処理と表記 した棒グラフは，物理的処理の効果を調べるための無処 理のサンプルの初期值における值を示している. 同図よ り処理前でも約 $8 \%$ の細胞の遊泳停止が認められる。こ れは顕微鏡観察等などの実験環境下におけるストレスが 原因であると考えられる．無処理のケースAにおいて時 間の経過とともに遊泳停止細胞が増加するとともに12日 後には枯死細胞が確認されているが, これは自然条件で も生じる細胞活性の低下や枯死であると考えられる.

処理1日後以降の処理ケースの結果を無処理ケースと 比較すると，遊泳停止細胞もしくは枯死細胞の細胞数の 割合は処理ケースの方が大きく，処理により遊泳細胞数 の割合が減少していることがわかる．これは物理的処理 の効果を示していると考えられる，処理ケースでは，処 理直後に全細胞が遊泳を停止したが，その数時間後には 再遊泳による遊泳細胞が増加し始め，1日後には遊泳細 胞の割合が5割以上に達している。ただし，それ以降は 遊泳細胞の顕著な増加は生じず，12日後には枯死細胞が 増加している。なお処理効果として，たとえば処理2日 後で比較すると, 遊泳停止細胞の割合はケースB(処理) の方がケースA(無処理)に比べて約 $20 \%$ 多い.

顕微鏡観察によれば処理直後に遊泳停止している細胞 


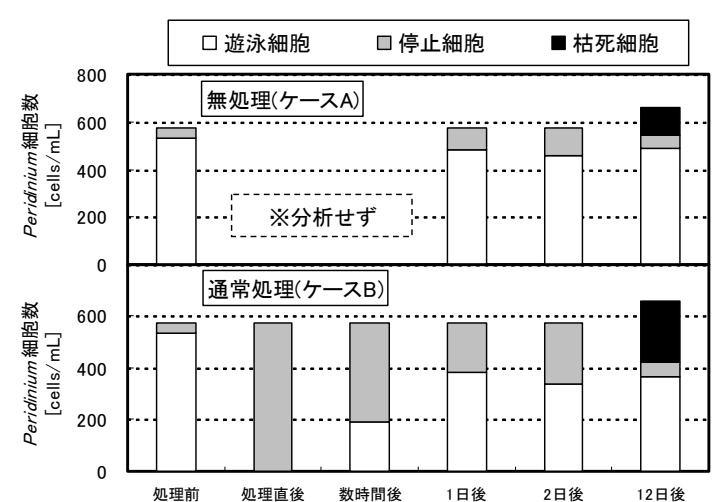

図-2 物理的処理による細胞遊泳状態の変化

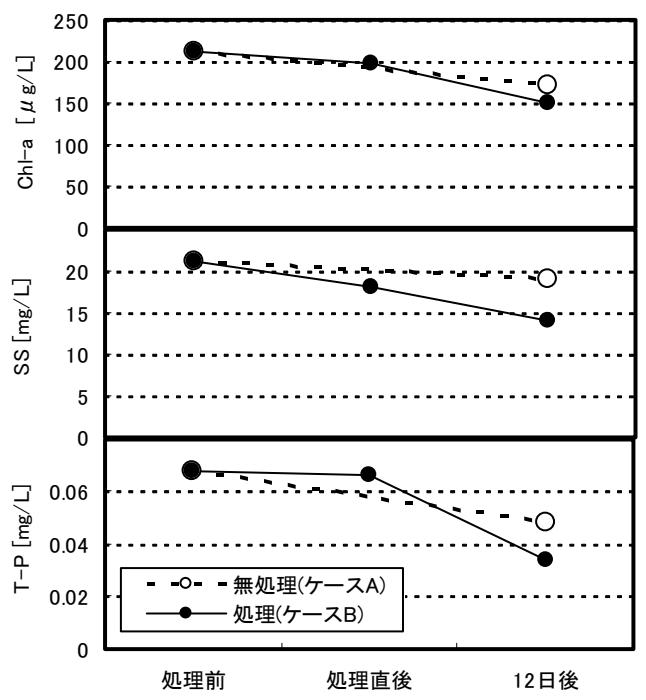

図-3 物理的処理による上澄み水への影響

には，破壊や損傷は認められなかった．採用した物理的 な処理手法は細胞を破壊するのではなく，機械的ストレ スを与えて遊泳能力を奪う作用があると推測される。ま た，遊泳停止した細胞の中でダメージの小さい細胞は処 理後約1日程度の間に突発的な微動・回転・移動などを 行いながら再遊泳に至るようになることも確認された。

\section{b）上澄み水質への影響}

図-3は物理的処理が上澄水質濃度に与えた影響を示し ている．各水質項目において，処理から12日間の経過に よって処理ケースで濃度低下が生じたことがわかる．特 にSSにおいてこの傾向が顕著であった．これは，処理に よるPeridinium細胞の沈降の結果，上澄み水の水質が改 善されたことを示している. 淡水赤潮形成時に水質とし て測定される物質は，その一定以上が赤潮藻類の細胞そ のものであるために，細胞沈降作用が上澄み水質改善効 果となると考えられる.なお，処理と無処理ケースとで の12日の遊泳細胞割合の違いと水質濃度の違いは概ね各 項目で2割程度であることも，これを裏付けている.

\section{c）植物プランクトンへの影響}

図-4 (a) は物理的処理が上澄み水中の植物プランクト ンに与えた影響を示している. なお，試料水中の植物プ ランクトンとしては渦鞭毛藻類のPeridiniumが $99 \%$ 以上 を占めていた。 このため, 他の植物プランクトンである

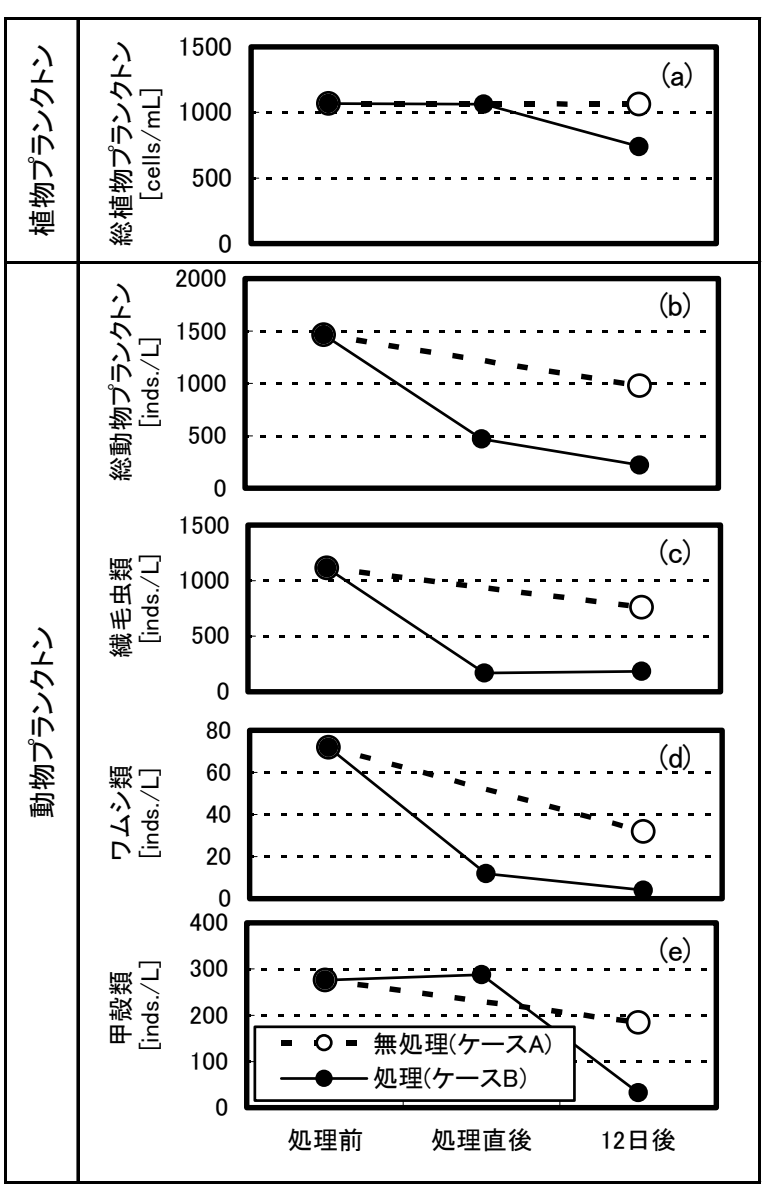

図-4＼cjkstart処理による上澄み水の動植物プランクトンへの影響

珪藻類と緑藻類の記述は省略し, 総植物プランクトン細 胞数のデータのみ示した. 植物プランクトンの総細胞数 は無処理のケースでは12日間殆ど一定であるのに対して， 処理ケースは2割から4割減少している。これは, 図-2で 示した遊泳能力の欠如したPeridiniumが沈降し，上澄み 水中のこれらの細胞数が減少した結果であると考えられ る。

\section{d）動物プランクトンへの影響}

図-4(b)〜 (e) は物理的処理が上澄み水の動物プランク トンに与えた影響を示している. 試料水中には動物プラ ンクトンとして繊毛虫類，ワムシ類，甲殼類が観察され たため，これらの分類群別にも示した．なお，それぞれ の主要な種は, 多膜網のフデッツカラムシ (Tintinnidium fluviatile), ヒゲワムシ (Polyarthra vulgaris), ゾウミジン コ (Bosmina longirostris)であった.

動物プランクトンの総個体数に基づいて処理効果を評 価すると，処理の12日後には約 $85 \%$ 減少している. 個別 の分類群で見ると，処理による異なった影響があること がわかる. 甲殼類以外の動物プランクトンは，処理直後 および12日後には無処理ケースに対して大幅に減少して いる. 一方甲殼類の個体数は処理直後の減少はみられな い.こうした処理直後の分類群による違いは，物理的処 理に対する抵抗性の違いであると考えられる. 以上より 本実験条件においては，物理的処理は動物プランクトン を減少させる効果があったと評価される. 


\section{3. 物理的処理の効果に関する考察}

\section{(1) 渦鞭毛藻類への直接的作用機構}

前報1)では，本報で使用したものと同様な物理的処理 装置を使用してアオコ形成藍藻類のガス胞を高圧で破壊 して沈降させるとともに強い乱れによる群体破壊で捕食 圧を高くするというメカニズムを用いた対策手法を提案 した．ところがPeridiniumはガス胞を持たない上に群体 で存在しないため, 同様なメカニズムによる効果は期待 できない，渦鞭毛藻類を含む様々な動物プランクトンは 水深 $100 \mathrm{~m}$ 以上の高圧環境でも存在していることから ${ }^{23)}$, 圧力そのものによる効果は考えにくい.

本対策は自然条件では生じにくい力学的ストレスを鞭 毛に作用させることによって遊泳停止作用を生じさせる と推定される. 渦鞭毛藻類の中でも淡水赤潮の原因とな るPeridinium属やCeratium 属の含まれるぺリディニウム 目は，細胞周囲を囲む複数の硬い殼どうしの間の溝に存 在する縦横2種類の鞭毛の機能分担により, 直進だけで なく急発進や急停止，方向転換等の遊泳を行っている ${ }^{24)}$ 細胞の長さスケールは10１00 $\mu \mathrm{m}$ であるために細胞遊 泳に関するレイノルズ数は自然条件では小さく層流環境 で遊泳機能が発現している. 自然条件では鞭毛は粘性の 卓越した「ゼリー状」の水中で運動しており, 処理時に 生じるような強いせん断流を経験することはないと考え られる. 鞭毛は直径約 $0.2 \mu \mathrm{m}$ の微細な毛状細胞であり特 に機械的ストレスへの抵抗作用のある構造も認めらない ことから，外的擋乱には弱いことが推察される. 寸なわ ち, 処理時には細胞構造の破壊には至らないものの鞭毛 に対しては何らかの機械的ストレスが作用して運動能力 が阻害された結果，遊泳停止が生じると考えられる.

なお，同じ渦鞭毛藻類でも細胞形状の異なる Peridinium属とCeratium 属では作用機構が異なることに 注意が必要である。例えば，井芹ら ${ }^{20} は$ は $0.5 \mathrm{Mpa} の$ 加圧衝 撃処理で約95\%のCeratium hirundinellaが死滅したと報告 しており，Peridiniumに関する結果(図-2)より効果的であ る.この原因はC. hirundinellaの細胞形状が細長く大型 (長径約 $200 \mu \mathrm{m}$ 弱)であるために, 加圧衝撃によって細胞 中央部の横溝や縦溝部分が破壊され易いためであると考 えられる ${ }^{21)}$.

\section{（2）水質浄化および低生態系への間接的作用機構}

本報の実験によって, 物理的処理により上澄み水の水 質は向上することが明らかとなった(図-3).これは Peridiniumの沈降に伴う効果であると考えられる. 淡水 赤潮発生時は, 赤潮藻類の動態そのものが栄養塩等の物 質輸送で支配的な要因となる ${ }^{25}$. したがって, 淡水赤潮 発生時の表層水質の改善効果も本処理は有していると評 価される. 処理した藻類の沈降に伴う水質改善効果の機
構は, 既報のアオコ処理の場合 ${ }^{1)}$ と等しい. ただしアオ コ形成藍藻類のほぼ $100 \%$ が処理によってガス胞が破壊 され沈降したことに比べると，Peridiniumに対する効果 は小さかった. この効果率の評価については, 淡水赤潮 対策という観点汃ら現地の貯水池における淡水赤潮の動 態を考慮して次節で議論を行う。

なお，低次生態系に対しても本処理は間接的な影響を 与えることによって水質浄化に寄与寸る可能性がある. アオコ処理の結果 ${ }^{20}$ とは対照的に, 本実験では処理に よって動物プランクトンが減少した。これはPeridinium の細胞が大型であり動物プランクトンに捕食されにくい ことが原因であると考えられる，ただしPeridiniumの減 少は，競合者である小型種を含む他の植物プランクトン の優位性向上に作用する可能性があること，そうした場 合には動物プランクトンにとっても餌資源が豊富になる ことによって水界生態系の多様化を生じる可能性がある と推測される.しかしながら一般に食物連鎖網は複雑な 相互作用からなっていることから，生態系をこのように 単純化した上で対策効果を期待することは, 現地での確 実性において問題があり, 更なる研究が必要である.

こうした効果を現地で効率よく発現させるためには, 後述するような現地での淡水赤潮の動態や発生機構等を 考慮した対策の実施が必要となる.

\section{4. 対策手法の提案と残された課題}

\section{（1）対策手法の基本原理}

本報で提案する淡水赤潮対策手法は, 淡水赤潮発生機 構の無効化を図るものである. 赤潮藻類の動態は, (1) ストの発芽を含む栄養細胞の水域への出現(発生過程), (2)増殖(発達過程), (3)増殖個体群の上流端表層部一の局 所集積(濃縮過程), (4)赤潮の消滅(消失過程)からなる3). ただし天野らつが述べているように持続的な淡水赤潮の 発生には上流端表層での局所集積が必要であることから (2)と(3)分離しがたい. 本手法は, 後述する作用によっ て集積機構を阻害し，もって赤潮藻類の個体群減少を図 ることを期待するものである. なお，既報のアオコ1)や Ceratium 属 ${ }^{20}$ に比べるとPeridiniumの処理効率は低いが, 後述するようにPeridiniumの淡水赤潮発生機構を考慮す れば，効果が期待できる細胞数割合が低いながらも現地 における淡水赤潮現象の抑制が期待できると考えられる. 赤潮藻類の局所集積は, 貯水池表層水の流入端に向う 流れと, 昼間の赤潮藻類の上方への遊泳で生じる 2),3,7,7,8,177). こうした現象を水理的に制御しようとする フェンスが淡水赤潮対策として提案されている ${ }^{9,12,17)}$. ところが，実際の貯水池では水位变動幅が大きいことが あり，適切なフェンス設置位置が流程方向に大きく移動 する傾向があり，実用上は課題がある，本報で提案する 対策は上述した局所集積要因のうち, 生物学的な過程で 
ある赤潮藻類の遊泳を阻害しようとするものである. 赤潮藻類の上方一の遊泳の要因としては，光に向う正 の走光性 ${ }^{3)}$ ，重力方向と逆に向う負の走地性年等がある Kishimoto et $\mathrm{al}^{6}{ }^{9}$ は, 室内実験, 現地観測および数值解析 結果に基づいて，淡水赤潮の集積状況の昼夜変動は，走 光性だけでなく走地性の双方のバランスが昼夜で異なる ことから発現していると結論づけている. 寸なわち, 夜 間においては明暗条件に無関係に発現する走地性のみが 機能して走光性による指向性が生じないために，数割か ら半分程度の細胞が上方への遊泳を行わなくなる. その 結果として, 表層に集積した淡水赤潮状態が解消される。 岸本らの提案する両走性を考慮した遊泳モデルによれば, 夜間における局所集積の解消は，約 $27 \%$ の細胞が上方遊 泳を停止したことによって生じていると見積もられる27. 本実験では，処理直後は $100 \%$ の細胞が，1日後以降は対 照区に比較すると約 $20 \%$ の細胞が遊泳を停止した．定量 的な解析を行う必要が別途あるが，本対策で効率よく赤 潮藻類の取水を行えば昼間でも局所集積を妨害し，もつ て赤潮藻類個体群の持続的発生を阻害して赤潮藻類個体 群の減少を生じせしめる可能性があると考えている.

\section{（2）対策適用にあたっての予備的考察}

本研究で提案した物理的処理手法を実際の貯水池に適 用してゆく上では，(1)設置位置，(2)施設規模，(3)効率化 のための他施設との一体化を考慮する必要がある．本論 文はこれらについて具体的な方法論を示寸研究段階には 達していないが，今後の研究展開の視点を明確にするこ とを念頭において以下に対策適用に当たっての予備的考 察を行った.

設置場所については，淡水赤潮の発生しやすい上流端 が好ましい，これは，赤潮解消という観点だけでなく， 上方への遊泳と表層流によって自己集積する赤潮藻類の 性質を活用して，処理水の細胞濃度を高くすることによ る処理効率を向上させるためである.ただし, 現地の地 形や気象, 赤潮発生特性を考慮した設置位置と寸る必要 がある。

施設規模については，処理による現存量の減少量が現 地におけるPeridiniumの増殖量を上回るような処理量の 確保が必要となる。一般的に渦鞭毛藻類はアロメトリー と遊泳運動へのエネルギー分配のために増殖速度が遅い 傾向があることから ${ }^{28)}$, 他の藻類に比べて個体群減少の ために必要な処理量は少なくて済む傾向がある，紙面の 都合上詳細は別途報告するが，実験で得られた遊泳停止 率を前提とすれば対象面積と施設規模との関係が 0.2 $1 \mathrm{ha} / \mathrm{m}^{3} / \mathrm{min}$. 以下であれば対策効果が期待できると著者 らは考えている.

処理効率の向上のためには，昼間に表層集積して上流 側に水平移動する高濃度の赤潮藻類を効率的に取水する ことが重要となる．このためには，フェンスを本対策の 補助施設として用いることが好ましい. なお，近年適用
例の多いフェンスを ${ }^{29}$ 植物プランクトン対策として実施 した場合には，フェンス上流に隔離したアオコや赤潮が 出水時に下流側に漏出してしまい, 効果が限定的になっ てしまうことも報告されている30). 本対策をフェンスと 併設することによって，フェンス上流側で隔離した赤潮 藻類を減少させることが期待できることから，この組み 合わせは互いの対策のデメリットを補い合う相乗作用を 発揮すると考えられる.

以上の設置位置, 施設規模, フェンスとの一体化につ いては, アオコ対策の設置条件 ${ }^{31)} と の$ 共通性が高い。し たがって，本対策はアオコおよび淡水赤潮の両現象に対 寸る対策施設として活用できる可能性がある．たとえば 同一施設を異なった水域に移動して使用する等の用途が 考えられる. 同一貯水池でPeridinium 属による赤潮と Ceratium属による赤潮が夏季と冬季とで交互に生じる場 合や，アオコと淡水赤潮が同じ水域で生じる場合もある 32). 本処理はCeratium 属 ${ }^{20}$ やアオコ形成藍藻類 ${ }^{1}$ に対して も効果が期待されることから，本対策施設は多目的藻類 対策としての活用も考慮する必要があろう.

\section{（3）残された課題}

物理的な処理によるPeridiniumの遊泳停止機構や原理 を明らかにするために，更なる実験的検討が必要である. また動物プランクトンへの影響については，本実験では 前処理でホルマリン固定を行ったために凝縮により同定 できなかった細胞もあると考えられるために，今後は生 サンプルによる効果評価も必要である. これらを前提と した検討を行うことにより, 処理効率の高い物理的機構 を提案し，構築することが可能となる．特にアオコ対策 施設と共有できるかどうか， あるいは赤潮対策としての 施設構造等の変更の必要性についての検討も必要である.

また，工学的な適用にあたっては，現地の気象流況特 性に合わせた最適な設置位置や規模等の計画方法を構築 する必要がある。こうした計画には処理による遊泳停 止・再遊泳・再増殖等を考慮したPeridiniumの動態モデ ルの開発も必要である.

\section{5. まとめ}

（1） 貯水池の淡水赤潮対策として現地貯水池で発生し ている洞鞭毛藻類(Peridinium bipes)を用いて物理 処理手法の効果を検討するための実験を実施した.

（2）実験の結果，処理直後はほぼ100\%，数時間経過 後から10日後までは自然状態に比較して2割強の Peridinium 細胞の遊泳能力を失わせることが可能 であることが明らかとなった。

（3）遊泳能力を失った渦鞭毛藻類細胞が沈降寸ること で上澄み水の水質が改善することが確認された.

(4) これらの効果に基づいた本処理手法を活用した対 
策手法について，原理や適用方法を検討した.

謝辞 : 本研究の遂行にあたっては，独立行政法人水資 源機構池田総合管理所および西日本技術開発株式会社の 井芹寧博士の協力を得た. また, 龍谷大学の岸本直之教 授にはPeridiniumの走地性や淡水赤潮の集積機構につい て有益な助言を得た.ここに記して謝意を示す.

\section{参考文献}

1) 古里栄一, 藤野毅, 浅枝隆, 有田正光 : 物理的処理による アオコ対策の効果に関する基礎的実験，水工学論文集，54, pp.1483-1488, 2010.

2) 宗宮功, 岸本直之 : ダム貯水池で発生する淡水赤潮の現状 と問題点，ダム技術，No.144，pp.4-10， 1998.

3) 山田正人 : ダム湖上流端水域におけるPeridinium淡水赤潮の 集積機構に関する研究, 京都大学学位論文, 1995.

4) Sako, Y., Ishida, Y., Kadota, H., and Hata, Y.: Excystment in the Freshwater Dinoflagellate Peridinium cunningtonii, Bulletin of the Japanese Society of Scientific Fisheries, 51, pp.267-272, 1985.

5) 岸本直之, 大西庸介, 大西正記, 宗宮功: 淡水性渦鞭毛藻 Peridinium bipesの増殖・死滅速度に及ぼす水温・光強度の 影響, 陸水学䧱誌, 59, pp.295-310, 1998.

6) Kishimoto, N., Ohnishi, Y., Somiya, I., and Ohnishi, M.: Geotaxis in the Freshwater Dinoflagellate Peridinium bipes f. occultatum, Japanese Journal of Limnology, 60, pp.299-317, 1999.

7) 天野邦彦, 田中康泰, 鈴木宏幸, 安田佳哉：貯水池末端 における持続的な淡水赤潮に関する研究，水工学論文集， 44 , pp.1083-1088, 2000.

8）畑幸彦: 永瀬ダム湖におけるPeridiniumによる赤潮現象，国 立公害研究所研究資料, 24, pp.15-28, 1983.

9）松尾直規，山田正人, 宗宮功: 貯水池上流端における流動 特性と淡水赤潮現象との関係, 水工学論文集, $40, \mathrm{pp} .575$ 581，1996.

10) 池田知司, 渡辺雄二, 三木眞弘, 大西庸介, 簤持和洋, 清 原正高, 宮永洋一, 石田祐三郎, 河合章 : 数值モデルによる 淡水性洞鞭毛藻Peridinium bipes fo. Occultatum の増殖要因の 解析, 陸水学䧱誌, 56, pp.107-124, 1995.

11) Kishimoto, N., Somiya, I., Ohnishi, Y., and Nakamura, T.: Mathematical simulation on accumulation process of a blooming plankton Peridinium bipes (Dinophyceae) in a dam reservoir, Water Science and Technology, 1, pp.37-48, 2001.

12) 松梨志郎, 今村正裕 : ダム貯水池の冬季の淡水赤潮の発生 状況と数值解析によるフェンスの対策効果の検討, 水工学論 文集，54，pp.1477-1482，2010.

13) 井芹寧, 川端善一郎, 藤本健二, 伊藤通陽 : 紫外線照射に よるプランクトンコントロール，用水と廃水，38, pp.31-37, 1996.

14) 井芹寧, 横山保夫, 吉村佐 : フェンスによるダム貯水池の 濁水・富栄養化防止対策，日本水処理生物学会誌，別巻16, pp.97, $1996 b$.

15) 岸本幸雄, 旗持和洋，前田広人 : 鉛直循環による淡水赤潮 発生対策について, 日本水産学会誌, 62, pp.3-11, 1996.

16) 高田利彦: ダム湖の富栄養化に関する研究一表面取水によ る神流湖の淡水赤潮の抑制一, 水資源開発公団試験所年報 1979年, pp.191-201, 1980.

17) 岸本直之：ダム貯水池における渦鞭毛藻Peridnium bipesに よる淡水赤潮の形成要因に関する研究, 京都大学学位論文, 2000.

18) 秋山壽一郎, 重枝未玲, 安藤祐馬, 小野修平, 小川真由 子 : フェンスによる貯水池潜入密度流の流動制御, 水工学論 文集，50，pp.1285-1290，2006.

19）寺川陽, 福渡隆 : ダム湖の富栄養化対策の動向, ダム技術, 136, pp.31-39, 1998.

20) 井芹寧, 横山保夫, Elixat Rahim : 物理的衝撃を用いた富栄 養化防止手法について, 日本陸水学会第65回大会講演要旨集, p78, 2000.

21) 井芹寧 : 私信, 2005 .

22) 建設省河川局 : 河川水質試験方法（案）1997版, 1997.

23) 高橋正征, 古谷研, 石丸隆 : 生物海洋学, 東海大学出版会, 1996.

24) 宮坂郁 : 渦鞭毛藻の遊泳のモデル化一細胞レベルのアプ ローチー, Bull.Plankton Soc.Japan, 49, pp.38-40, 2002.

25) 井上徹教, 井芹寧, 長谷部崇, 西元誠, 小松利光 : 渦鞭毛 藻Peridinium bipesの鉛直移動が栄養塩循環に及ぼす影響, 環 境工学研究論文集, 37, pp.445-453, 2000.

26) 古里栄一, 松宏典, 田畑隆一郎, 浅枝隆, 須藤隆一, 井芹 寧 : シアノバスター（浅い水域における藍藻類増殖抑制対策 手法）に関する研究開発( II) 一現地実験に基づく水界生態系 の改善効果の検討一, 土木学会第58回年次学術講演会要旨集 (VII), pp.103-104, 2003.

27) 岸本直之 : 私信, 2010.

28) Geider, R.J.: Light and Temperature Dependence of the Carbon to Chlorophyll a Ratio in Microalgae and Cyanobacteria: Implications for Physiology and Growth of Phytoplankton, New Phytol., 106, pp.1-34, 1987.

29) 牛島健, 藤田俊司, 草場智哉, 森川一郎, 熊谷清, 土居邦 弘：日本のダム貯水池の水質の現状と水質保全対策につい て, 大ダム, 208, pp.51-58, 2009.

30) 松尾直規 : 貯留水の流動特性と藻類の増殖及び集積現象と の関係, 湖沼, 貯水池の管理に向けた富栄養化現象に関する 学術研究のとりまとめ（代表者 : 浅枝隆）, pp.243-302, 土 木学会水理委員会, 環境水理部会, 2000 .

31) 福井正泰, 秋竹孝雄 : 阿木川ダムにおけるアオコ発生初期 の対策とその効果に関する検討，ダム技術，224，pp.62-70， 2005.

32) 高橋徹馬, 奥村勉, 増田稔, 柴田治信 : 石手川ダム湖にお ける赤潮抑制対策について，ダム技術，80，pp.34-44，1993.

(2010. 9. 30受付) 